\title{
MazEF homologous Modules System and A Post-segregational killing Mechanism (Bacteriostatic \& Bactericidal Mechanism) of Novel Compound Isolated from Spondias monbinon Escherichia Coli and Bacillus Subtilis
}

\author{
Oludare Temitope Osuntokun ${ }^{1 *}$, Olaposi A Omotuyi ${ }^{2}$ and Anthonia 0 Oluduro ${ }^{3}$ \\ ${ }^{1}$ Department of Microbiology, Adekunle Ajasin University, Nigeria \\ ${ }^{2}$ Centre for Biocomputing and Drug Development (CBDD), Adekunle Ajasin University, Nigeria \\ ${ }^{3}$ Department of Microbiology, Obafemi Awolowo University, Nigeria
}

Submission: February 14, 2019; Published: March 08, 2019

*Corresponding author: Oludare Temitope Osuntokun, Adekunle Ajasin University, Akungba Akoko, P.M.B 001, Ondo State, Nigeria

\begin{abstract}
The basic objective of this research work is to evaluate the mechanism of action of compound Epigallocatechin, Epicatechin and Stigmasterol Phytosterol (Synergy), Aspidofractinine-3-methanol) and Terephthalic acid, dodecyl 2-ethylhexyl ester with Selected clinical isolates by using molecular biomarker MazEF ${ }_{9}$ TA system. Toxin-Antitoxin (TA) systems are highly conserved in members of the Gram positive +ve and Gram negative -ve bacteria which has been proposed to play an important role in physiology and virulence. Clinical microorganisms were cultured and Sub-culturing in Department of Microbiology and Centre for Biocomputing and Drug Development (CBDD), Adekunle Ajasin University, Akungba Akoko, Ondo-state, Nigeria. A 12 hours old culture of each microorganism was re-suspended in plant extract at $1000 \mu \mathrm{gL}$ in a total volume of $500 \mu$ l for $0,15,30,45,60$, and 180 minutes. The cells were pelleted by centrifugation at 5000 revolution for 5 minutes, to isolate the DNA and total RNA was quantified using spectrophotometric absorbance at $260 \mathrm{~nm}$, the DNA was removed with Turbo DNA-free (Ambion, Inc.). The Removal of DNA from the RNA samples was performed using DNA-free ${ }^{\mathrm{TM}}$ DNA Removal Kit Reverse Transcription-PCR reaction in a $15.0 \mu \mathrm{L}$ final volume. $1 \mu$ l template cDNA ( $\sim 40 \mathrm{ng}$ ) were combined with $1.0 \mu \mathrm{L}$ of forward primer $(5 \mathrm{nM}), 1.0 \mu \mathrm{L}$ of reverse primer $(5 \mathrm{nM}), 4.5 \mathrm{~mL}$ nuclease-free water and 7.5 $\mu \mathrm{L}$ of Taq 2X Master Mix. Assessment of Polymerase Chain Reaction products (amplicons) were electrophoresed in $0.5 \%$ of agarose gel using $0.5 \times$ TBE buffer (2.6g of Tris base, $5 \mathrm{~g}$ of Tris boric acid and $2 \mathrm{~mL}$ of $0.5 \mathrm{M}$ EDTA and adjusted to $\mathrm{pH} 8.3$ with the sodium hydroxide pellet) with $0.5 \mu$ Lethidum bromide. The bacteriostatic mechanism of action of isolated compounds $\mathrm{A}_{1}, \mathrm{~A}_{3}$ and $\mathrm{F}_{3}$ from the Stem bark of Spondiasmombin. The bacteriostatic mechanism of action was demonstrated with the selected biomarker MazF against E. coli and B. subtilis. It was observed that at 30 minutes, the mechanism of action is bacteriostatic action on the test organism (B. subtilis). By overexpressing putative MazF homologues in clinical isolates $\left(\mathrm{MazF}_{9}\right)$ induce bacteriostasis. MazFribo nucleases contribute synergistically to the ability of clinical isolates to adapt to conditions such as nutrient depletion and rapid progress to the death thereby measuring the reversible bacteriostatic mechanism of action of isolated novel compound from Spondiasmombin the novel compound is $\mathrm{A}_{1}$ (Epigallocatechin, Epicatechin and Stigmasterol phytosterol (synergy), $\mathrm{A}_{3}$ (Aspidofractinine-3-methanol) and $\mathrm{F}_{3}$ (terephthalic dodecyl 2-ethylhexyl ester) isolated from Spondiasmombin. The use of medicinal plant like Spondiasmombin should be encourage because of its therapeutic properties in the prophylaxis cure of infectious disease.
\end{abstract}

Keywords: Post segregational killing mechanism epigallocatechin; Epicatechin; Stigmasterol phytosterol; Mazef TA System; Bacteriostatic

\section{Introduction}

Spondiasmombin L. (Anacardiacaea) also known as hog plum is a plant that grows in almost every part of the world. It is fruit feriousdecidous plant of about $20 \mathrm{~m}$ high that grows in the rain forest and the coastal area of Africa. It is known locally as "iyeye" by the Yoruba people of Nigeria Ripped fruits are eaten out hand by the old and young and processed into ice-cream, cool beverages, wine, jam and other preservatives. Spondiasmombin also found application in folk medicine. Infusion of its leaves has been used for a long time, without any report of collateral effect due to its anti- vitrotic activity against the herpes virus [1]. A tea of the flowers and the leaves is taken to relieve stomachache biliousness, urethritis, cystitis and eye and throat inflammation. Herbalist in South Western Nigeria use the plant in the treatment of typhoid, tuberculosis, diabetics, nervous disorders and psychiatric disor- 
ders. Offiah, Anyanwu [2] have reported the abortifacient activity of the aqueous leaf extract of Spondiamombin. In addition, the anthelmintic, molluscicidal, anxiolytic, anti-bacteria, antiviral effect of the plant have been previously described. Idu et al. [3] reported the inhibitory activity of Spondiamombin against Cycasrevoluta induced carcinogenesis. The discovery of toxin-antitoxin gene pairs (also called homologous modules) on extra-chromosomal elements of Escherichia coli, Bacillus subtilis and particularly the discovery of homologous modules on the bacterial chromosome, suggest that a potential for programmed cell death may be inherent in bacterial cultures which is under the scope of this research work, this was reported on the E. coli / Bacillus subtilis mazEF system, a regulatable addiction module located on the bacterial chromosome. MazF is a stable toxin and a labile antitoxin.it show that cell death mediated by the E. coli /Bacillus subtilis mazEF module can be triggered by several medicinal plant extract and antibiotics like Rifampicin, chloramphenicol, and spectinomycinetc, that are general inhibitors of transcription and translation. These medicinal plant extract and antibiotics alike inhibit the continuous expression of the labile antitoxin MazE, and as a result, the stable toxin $M a z F$ causes bacteria cell death. The results of this research have implications for the possible mode(s) of action of this group of medicinal plant and antibiotics on selected clinical isolates. The mode of action of the medicinal plants may be either bacteriostatic or bacteriocide [4] but the scope of this research work is based on bacteriostatic mechanism of action of isolated novel compound on selected clinical organisms (E. coli and B. subtilis).

In Escherichia coli/Bacillus subtilis cultures, programmed cell death is mediated through a unique genetic system. This system, called "homologous module," consists of a pair of genes that specify for two components: a stable toxin and an unstable antitoxin which prevents the lethal action of the toxin. Until recently, such genetic systems for bacterial programmed cell death have been found mainly in E. coli and Bacillus subtilis on low-copy-number plasmids, where they are responsible for what is called the postsegregational killing mechanism. When bacteria lose the plas$\operatorname{mid}(\mathrm{s})$ (or other extra-chromosomal elements), the cured cells are selectively killed because the unstable antitoxin is degraded faster than is the more stable toxin [5]. Thus, the cells are "addicted homologous" to the short-lived product, since its de novo synthesis is essential for cell survival [6].Therefore, these homologous modules have been implicated as having a role in maintaining stability in the host of the extrachromosomal elements on which they are bounded, Jensen, Gerdes [7], once this stability is destroyed, this will inevitably leads to the death of the bacterial cell. Pairs of genes homologous to some of these extra-chromosomal addiction modules have been found on the E. coli and Bacillus subtilis chromosome Aizenman et al. [8], Gerdes et al. [9]. The mazEF module consists of two adjacent genes, $m a z E$ and $m a z F$, located in the rel operon downstream from the relA gene Metzger et al. [10].

In the study, $m a z E F$ was found to have the properties required for an addiction module:

\section{(i) MazF is toxic and MazE is antitoxic}

(ii) MazF is long lived, while MazE is a labile protein degraded in vivo by the ATP-dependent ClpPA serine protease

(iii) MazE and MazF interact

\section{(iv) MazE and MazF are coexpressed}

Both MazF and MazE are expressed thereby leading overexpressed killing effects of bacteria cell, Moreover, the mazEF system has a unique property: its expression is inhibited by guanosine $3^{\prime}, 5^{\prime}$-bispyrophosphate (ppGpp), which is synthesized under conditions of extreme amino acid starvation by the RelA protein [11] thereby leading to the death of the bacteria cell. Based on these properties of mazEF and on the requirement for the continuous expression of MazE to program cell death, members of our group offered a model for programmed cell death under conditions of nutrient starvation [8]. In this study, MazF (toxic) is used to stimulate the programme cell death of the clinical isolates and evaluates the efficacy of novel compound isolated from Spondiasmombn plant on the selected clinical organisms.

\section{Materials and Method}

\section{Microorganism for the research work}

Clinical microorganisms were used for this research work, which comprised Escherichia coli ATCC 25922and Bacillus subtilis.

\section{Sources of microorganisms}

All typed strains used for this research work were purchased from the University of Pennsylvania, School of Medicine, Philadelphia, United States of America (USA), in an America Type Culture Collection (ATCC), and the other locally isolated bacteria and fungi were clinical organisms collected from Central Medical Laboratory(CML), Obafemi Awolowo University Teaching, Hospital (OAUTH), Ile Ife, Osun State, and the Institute of Advance Medical Research and Training (IMRAT),University College Hospital, Ibadan, Oyo State Nigeria.

\section{Authentication of test microorganisms}

The identity of the test organisms was confirmed using Biomerieux, France, API 20E Kits for bacteria as specified by the manufacturer's instruction. Analytical Profile Index [12].

\section{Isolation of RNA.}

A 12 hours old culture of each microorganism was re-suspended in plant extract at $1000 \mu \mathrm{g} \mathrm{mL}$ in a total volume of $500 \mu \mathrm{l}$ for $0,15,30,45,60$, and 180 minutes. The cells were pelleted by centrifugation at $5000 \mathrm{~g}$ for 5 minutes. The pellets were rinsed twice in phosphate buffer saline (PBS). Then $1 / 10$ volume of $95 \%$ ethanol plus $5 \%$ saturated phenol were added to the pellets to stabilise cellular RNA. The cells were then re-harvested by centrifugation $\left(8200 \mathrm{~g}, 4^{\circ} \mathrm{C}\right.$ and 2 minutes). The supernatant was aspirated and pellets re-suspended in $800 \mu \mathrm{l}$ of lysis buffer (10mMTris, adjusted to $\mathrm{pH} 8.0$ with $\mathrm{HCl}, 1 \mathrm{mM}$ EDTA) and $8.3 \mathrm{U} / \mathrm{ml}$ Ready-Lyse 
TM Lysozyme Solution. After the pellets were re-suspended, $80 \mu \mathrm{l}$ of a $10 \%$ SDS solution was added, mixed and incubated for 2 minutes at $64^{\circ} \mathrm{C}$. Then $88 \mu \mathrm{l}$ of $1 \mathrm{M} \mathrm{NaOAc}$ (pH 5.2) was mixed with the lysate followed by an equal volume of water and saturated phenol was added. This was incubated at $64^{\circ} \mathrm{C}$ for 6 minutes while inverting the tubes every 40 seconds. The aqueous phase was separated following centrifugation at 21,000 g for 10 minutes at 4 ${ }^{\circ} \mathrm{C}$. The RNA was precipitated from the aqueous layer using $1 / 10$ volume of 3M NaOAc (pH 5.2), 1mM EDTA and 2 volumes cold EtOH and centrifugation at $21,000 \mathrm{~g}$ for 25 minutes at $4^{\circ} \mathrm{C}$. Pellets were washed with ice cold $80 \% \mathrm{EtOH}$ and centrifuged at $21,000 \mathrm{~g}$ for 5 minutes at $4{ }^{\circ} \mathrm{C}$. The ethanol was carefully removed and the pellets were air dried for 20 minutes. The pellets from each split sample were re-suspended in a total of $100 \mu \mathrm{l}$ of RNase-free water and combined into one microfuge [1].

\section{Synthesis of convertible (cDNA)}

Total RNA was quantified using spectrophotometric absorbance at 260nm DNA was removed with Turbo DNA-free (Ambion, Inc.). Removal of DNA from the RNA samples was performed using DNA-free ${ }^{\mathrm{TM}}$ DNA Removal Kit (Thermo Fisher) following manufacturer's protocol. Purified DNA-free RNA was converted to cDNA immediately using Proto Script ${ }^{\circledR}$ First Strand cDNA Synthesis Kit (NEB). The cDNA was diluted to a final volume of $286 \mu \mathrm{l}$ and stored at $4^{\circ} \mathrm{C}[1]$.

\section{Solation of RNA from bacterial cell}

\section{Figure 1.}

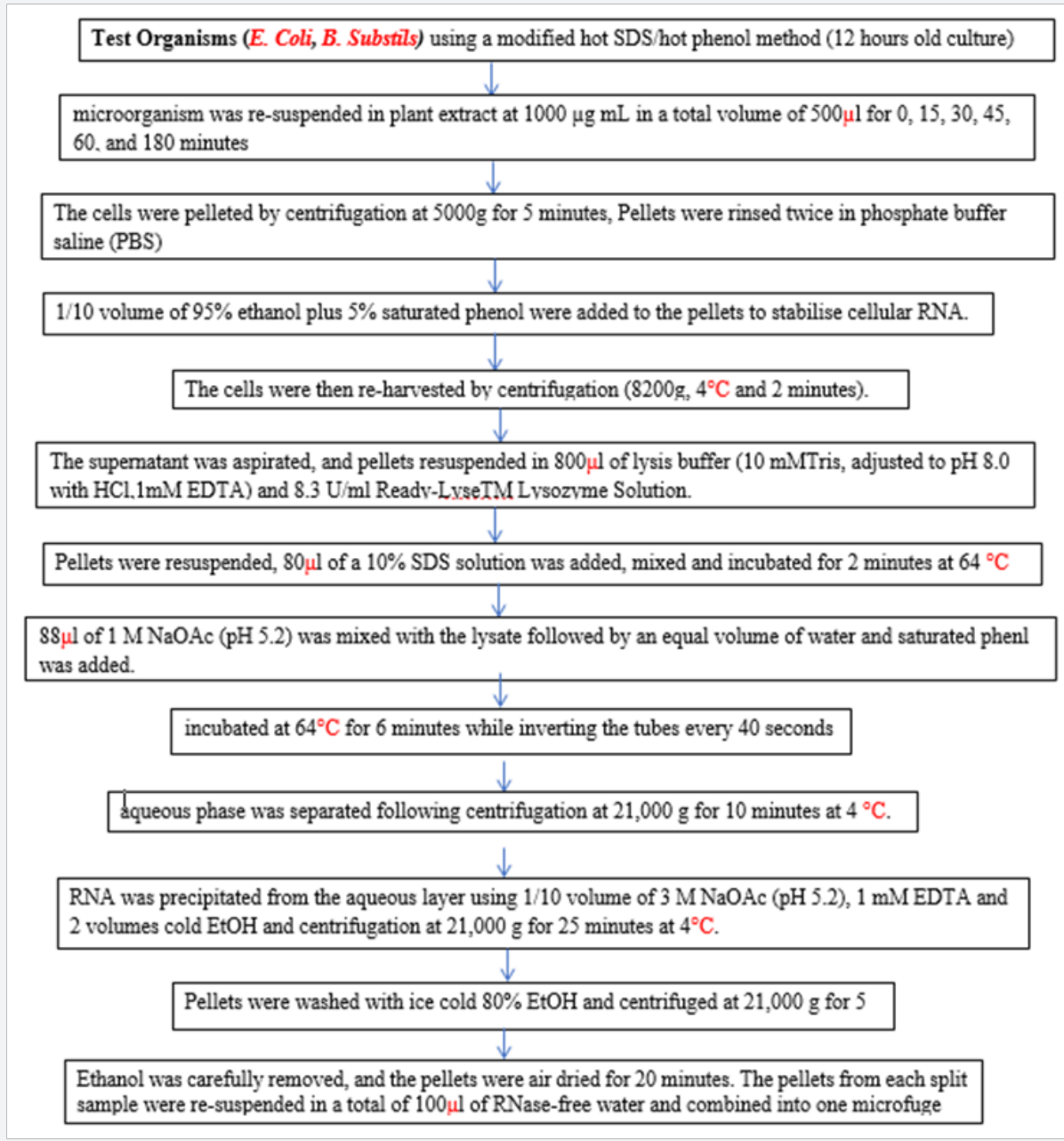

Figure 1: LPL lymphoid and plasmacytoid cells abutting the marrow trabeculae (Courtesy: Research Gate).

\section{PCR protocol}

Reverse Transcription-PCR reaction was performed in a $15.0 \mu$ l final volume. Briefly, $1 \mu$ l template cDNA ( $40 \mathrm{ng})$ was combined with $1.0 \mu \mathrm{l}$ of forward primer $(5 \mathrm{nM}), 1.0 \mu \mathrm{l}$ of reverse prim- er (5nM), $4.5 \mathrm{ml}$ nuclease-free water and $7.5 \mu \mathrm{l}$ of Taq $2 \mathrm{X}$ Master Mix. Thermo cycling was performed by 40 cycles at $95^{\circ} \mathrm{C}$ for 15 seconds, $60^{\circ} \mathrm{C}$ for 15 seconds and $72^{\circ} \mathrm{C}$ for 15 seconds. Analysis of the PCR products was performed using 1.5\% agarose gel 
solution in TBE buffer and visualisation was enabled by soaking gel in ethidium bromide solution for 10 minutes and UV-transilluminator. The data obtained were analyed using Graph pad prism version 6.01 description and frequency. statistic was generated to describe the diameter of inhibition. quantitative phytochemical constituent and toxicological prameter to test for the level of significance [1].

\section{Gel electrophoresis}

Assessment of Polymerase Chain Reaction products (amplicons) were electrophoresed in $0.5 \%$ of agarose gel using $0.5 \times \mathrm{TBE}$ buffer (2.6g of Tris base, $5 \mathrm{~g}$ of Tris boric acid and $2 \mathrm{ml}$ of $0.5 \mathrm{M}$ EDTA and adjusted to $\mathrm{pH} 8.3$ with the sodium hydroxide pellet) with $0.5 \mu$ lethidum bromide. The expression product was visualized as bands by UV-transilluminator [1] Table 1.

Table 1: Primers used for PCR molecular investigation, to determine the mechanisms of action of novel compound extraction from Spondiasmombin on selected clinical organisms.

\begin{tabular}{|c|c|}
\hline Target genes or Biomarkers & $\begin{array}{c}\text { MazEF TA homologous modules } \\
\text { (MazEF9) }\end{array}$ \\
\hline FORWARD 5'-3' & TGTTGTCGGCCACCACCTA CT \\
\hline REVERSE 5'-3' & GCAGTTTCAAAGCCTCATC \\
\hline REFERENCES & Tripathi et al. [23] \\
\hline
\end{tabular}

\section{Results}

The MazEFhomologous modules system and a Post-segregational killing mechanism (Bacteriostatic \& Bactericidal mechanism) of novel compound isolated from Spondiasmonbinon Escherichia coli and Bacillus subtilis were demonstrated in Figure 1-6.
The novel compound isolate from Spondiasmombin include the following, $\left(\mathrm{A}_{3}\right.$-Epigallocatechin, Epicatechin and Stigmasterol phytosterol (synergy), $\mathrm{A}_{3}$-Aspidofractinine-3-methanol) and $\mathrm{F}_{3}$ (Terephthalic acid, dodecyl 2-ethylhexyl ester) and the gene expression $\mathrm{MazF}_{9}$ was observed in Escherichia coli and bacillus subtilis. Figure 1 shows Bacillus subtilis, mazEF homologous modules system and Post-segregational killing mechanism (Bacteriostatic \& Bactericidal mechanism) of compounds $\mathrm{A}_{1}$ (Epigallocatechin, Epicatechin and Stigmasterol Phytosterol (Synergy), $A_{3}$ (Aspidofractinine-3-methanol) and $\mathrm{F}_{3}$ (Terephthalic dodecyl 2-ethylhexyl ester) by $\mathrm{MazF}_{9}$ (Toxin/ antitoxin sensor. In Figure 2,3 and 4. It was observed that compounds $A_{1}, A_{3}$ and $F_{3}$ have a deleterious effect on the cell (via DNA) of the test organism. At 180 minutes, the death phase was ascertained. This is graphically demonstrated in the figure1. Both MazE (toxin) and MazF (antitoxin) were produced, which both were used to activate the death phase of the cell through Post-segregational killing mechanism (Bacteriostatic \& Bactericidal mechanism) of MazEFhomologous modules system on E. coli and B. Subtilis. The compounds have bacteriostatic and bactericidal effect on the test organisms ( $E$. coli and $B$. subtilis). Figure 5 shows E.coli, mazEF homologous modules system and Post-segregational killing mechanism (Bacteriostatic \& Bactericidal mechanism)of $A_{1}$ (Epigallocatechin, Epicatechin and Stigmasterol Phytosterol (Synergy), $\mathrm{A}_{3}$ (Aspidofractinine-3-methanol) and $\mathrm{F}_{3}$ (Terephthalic dodecyl 2-ethylhexyl ester)by gene expression $\mathrm{MazEF}_{9}$ (Toxin/ antitoxin sensor ) bacteriostatic and bactericidal effect as the mechanism of action compounds of $A_{1}$, $\mathrm{A}_{3}$ and $\mathrm{F}_{3}$ as observed in (Figure 6-8) respectively.
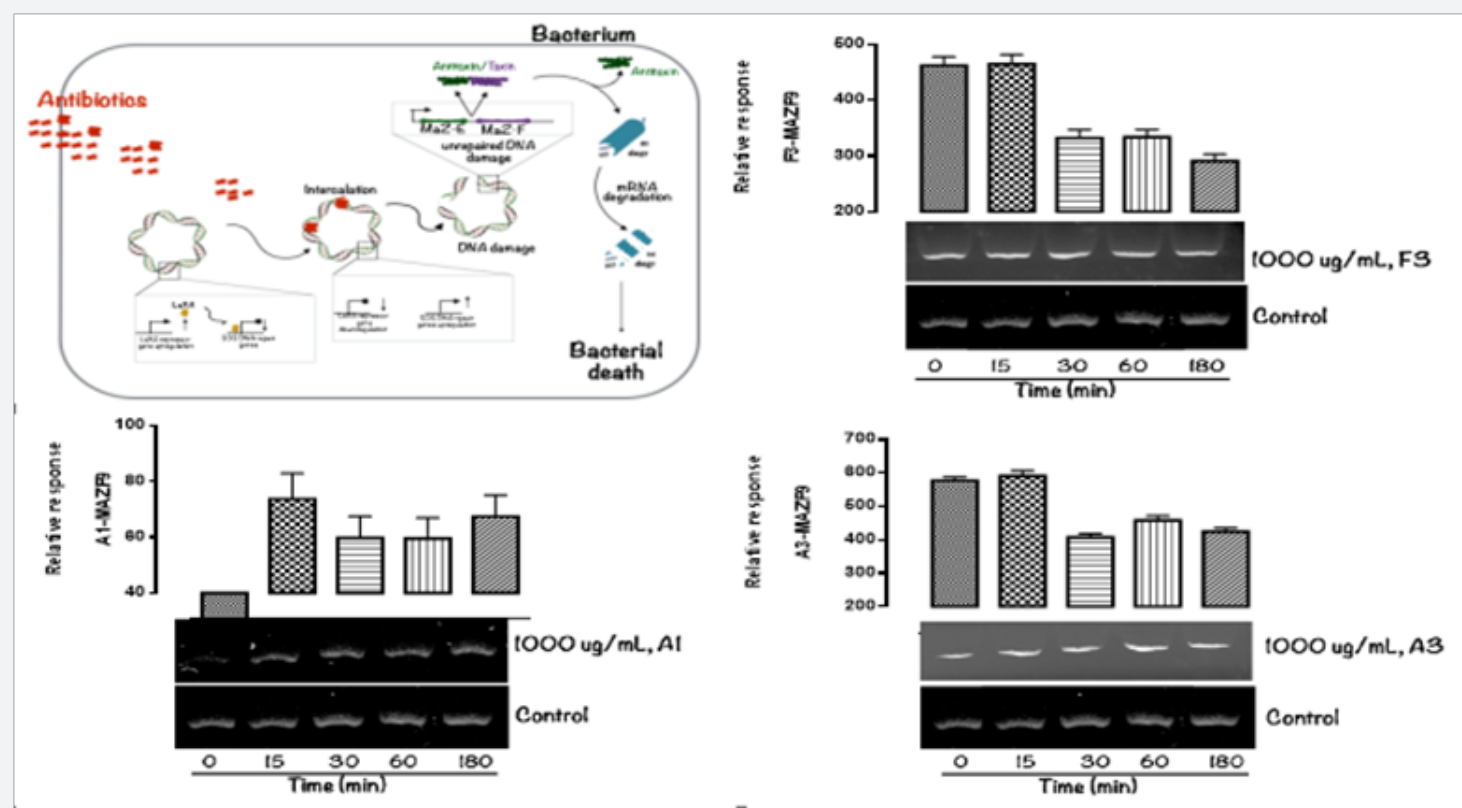

Figure 2:LAgarose Gel Electrophoresis of The Amplification of Product Coding MazF9 (393bp) Selected Interaction Between Gene and Cells (Ldder DN 100bp) (A-D), Bacteriostatic and Bactericidal Mechanism of Action of Isolated Compound A1, A3 and F3 From Spondiasmombin By Toxin-Antitoxin Sensor MazF9 on Bacillus Subtilis. 


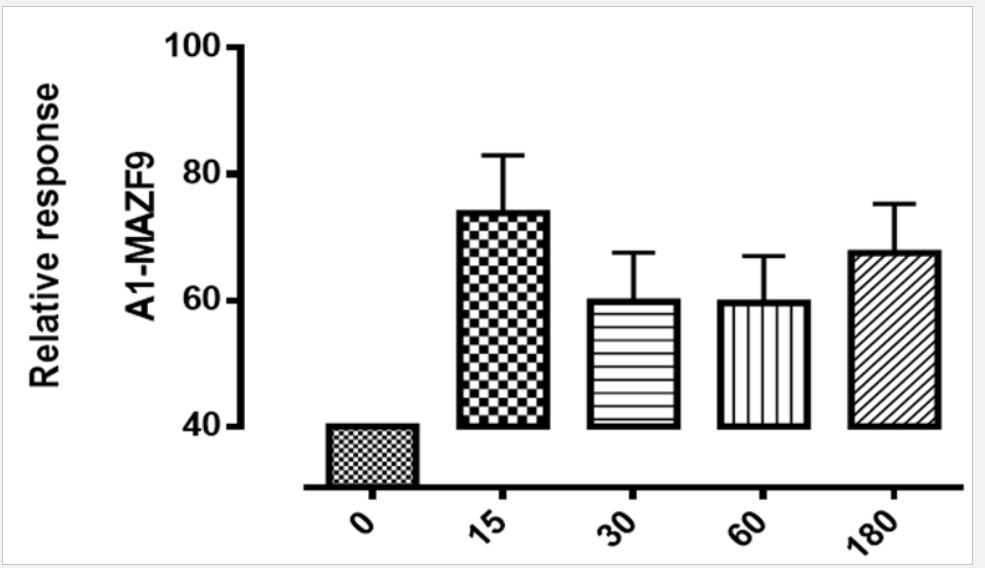

Figure 3:Bacteriostatic and Bactericidal Mechanism of Action of Isolated Compound A1(Epigallocatechin, Epicatechin and Stigmasterol phytosterol (Synergy) From Spondiasmombin by Toxin-Antitoxin Sensor MazF9 on Bacillus Subtilis.

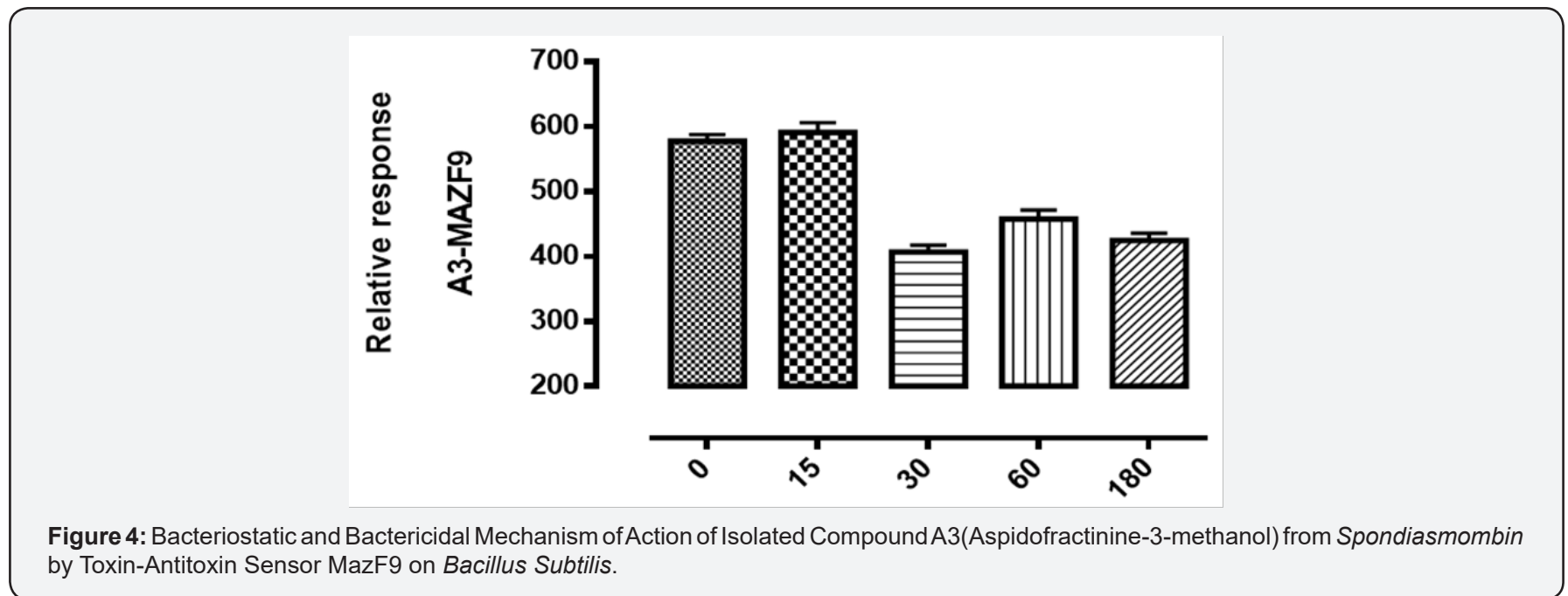

\section{Discussion}

The purpose of the research work is to determine the Post-segregational killing mechanism (Bacteriostatic \& Bactericidal mechanism) of novel compound isolated from Spondiasmonbinon Escherichia coli and Bacillus subtilis by MazEFhomologous modules system. action of compound $A_{1}$ (Epigallocatechin, Epicatechin and Stigmasterol Phytosterol (Synergy), $A_{3}$ (Aspidofractinine-3-methanol) and $\mathrm{F}_{3}$ (Terephthalic acid, dodecyl 2-ethylhexyl ester) with two Selected microorganism (Gram positive +ve), (Gram negative -ve) were demonstrated by toxin-antitoxin gene pairs (also called addiction modules) on extra-chromosomal elements of Escherichia coli, Bacillus subtilis All figs describe the mechanism of action of the isolated compound of ethyl acetate stem bark extract of Spondiasmombin extract. Nine of these TA systems belong to the mazEF family, encoding the intracellular MazF toxin and its antitoxin. Another mechanism of action of compound $A_{1}, A_{3}$ and $F_{3}$ on the selected microbe E. coli and Bacillus subtilis is by probing for the toxin-antitoxin Maz $\mathrm{F}_{9}$ bio sensor. It was observed that in Figure 1-3. $\mathrm{A}_{1} \mathrm{MazF}_{9}, \mathrm{~A}_{3} \mathrm{Maz} \mathrm{F}_{9}$ and $\mathrm{F}_{3} \mathrm{MazF}_{9}$ stimulate the pro- duction of toxin/antitoxin system in the cell of the microorganism, used for this study and a greater effect were found between 0 to 15 minutes and decrease in effect were found at 30 to $180 \mathrm{~min}$ utes, this effect of toxin-antitoxin leads to the death of the organism between 0 to 180 minutes, the death ratio is measured and cells were destroyed or damaged by stimulation of toxin-antitoxin system. Toxin-antitoxin system are induced to measure the death phase at 0-180 minutes and this study was conducted to investigate the role of $\mathrm{MazF}_{9}$ to isolated compound. It was also observed that over expression of $\mathrm{MazF}_{9}$ induced a state of irreversible bacteriostasis consistent with the results of the previous study [13$15]$. The main finding of this work is that $E$. coli mazEF-mediated cell death can be triggered by medicinal plant that are general inhibitors of transcription and/or translation. it was shown that these Spondiasmombin reduce the cellular level of the antitoxic labile protein MazE and seem thereby to permit the lethal action of the toxic protein MazF. The effect of the Spondiasmombin both on cell death and on the reduction in the cellular level of MazE [16]. 


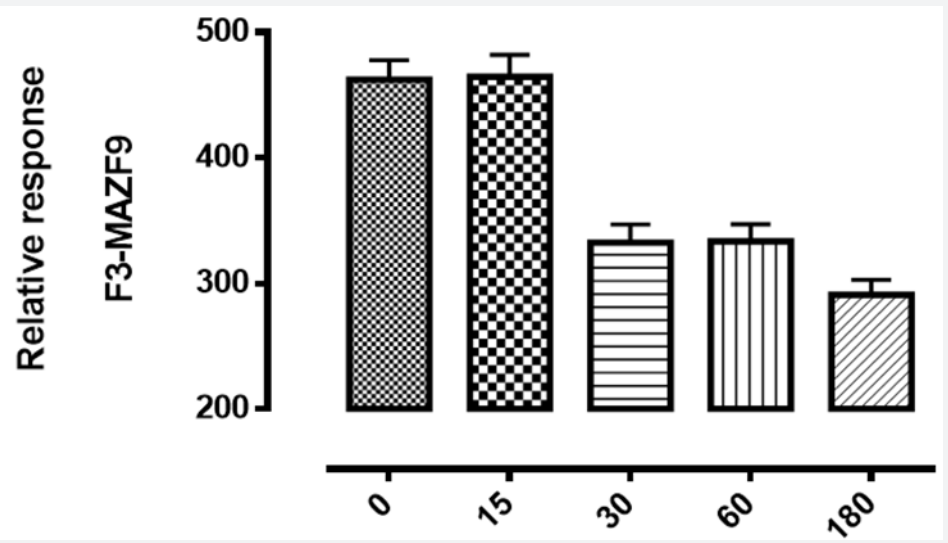

Figure 5: Bacteriostatic and Bactericidal Mechanism of Action of Isolated Compound A3(Aspidofractinine-3-methanol) from Spondiasmombin by Toxin-Antitoxin Sensor MazF9 on Bacillus Subtilis.
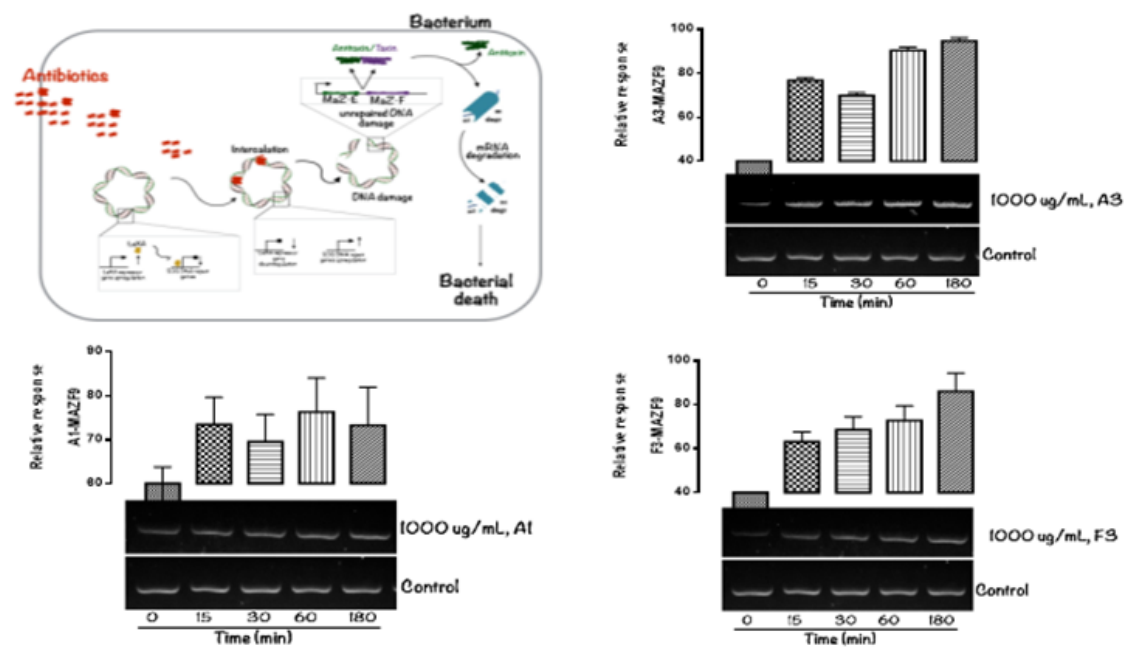

Figure 6: Agarose Gel Electrophoresis of The Amplification of Product Coding MazF9 (1283bp) Selected Interaction Between Gene and Cells (Ldder DN 100bp) (Bacteriostatic \& Bactericidal Mechanism of Action of Isolated Compound A1, A3 and F3 From Spondiasmombin By Toxin-Antitoxin Sensor MazF9 on Escherichia Coli.

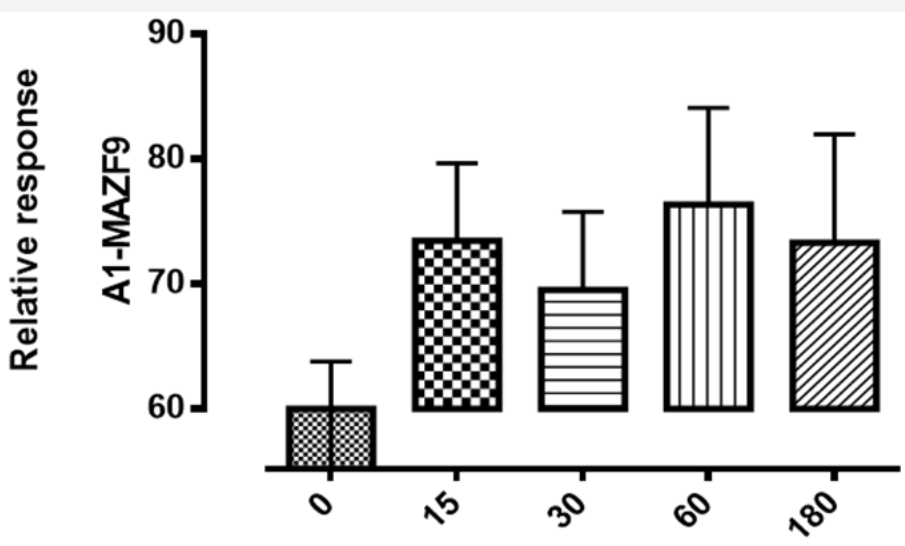

Figure 7: Bacteriostatic and Bactericidal Mechanism of Action of Isolated Compound A1(Epigallocatechin, Epicatechin and Stigmasterol Phytosterol (Synergy) From Spondiasmombin by Toxin-Antitoxin Sensor MazF9 on Escherichia Coli. 


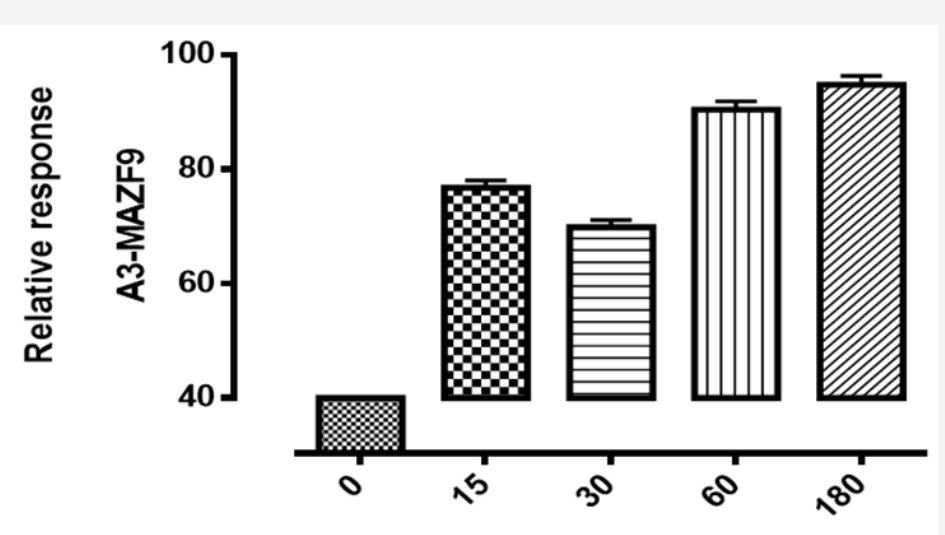

Figure 8: Bacteriostatic and Bactericidal Mechanism of Action of Isolated Compound A3 (Aspidofractinine-3-methanol) From Spondiasmombin by Toxin-Antitoxin Sensor MazF9 on Escherichia Coli.

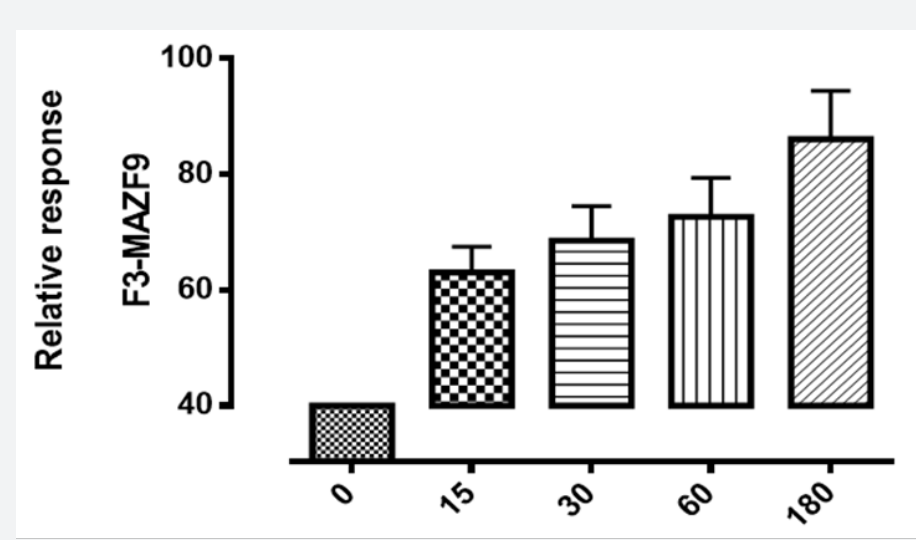

Figure 9: Bacteriostatic and Bactericidal Mechanism of Action of Isolated Compound F3 (Terephthalic dodecyl 2-ethylhexyl ester) From Spondiasmombin By Toxin-Antitoxin Sensor MazF9 on Escherichia Coli.

The isolated compound has a great effect on selected organism. It was observed that the effect of gene $\mathrm{MazF}_{9}$ has more lethal effects in E. coli, taking a cognizant from figure 5-8 represented by $\mathrm{A}_{1} \mathrm{MazF}_{9}, \mathrm{~A}_{3} \mathrm{MazF}_{9}$ and $\mathrm{F}_{3} \mathrm{MazF}_{9}$. It was observed that the compound complete inhibits the $E$. coli at 180 minutes i.e. the compound has a better activity on E. coli than B. subtilis. The reasons for this activity must be as a result of their cell wall, the Gram negative ( $E$. coli) has a greater activity because of a thin composition of the peptidoglycan cell wall compares to the gram positive ( $B$. subtilis) which has a large composition of peptidoglycan in the cell wall. The gram negative is easily affected by antibiotic compound and compares the gram positive with very thick cell wall, this account for the activity of $\mathrm{MazF}_{9}$ more on E. coli than B. subtilis but their death rate was constantly measured, and toxin-antitoxin activity were clearly depleted [17].

In analogy to the programmed cell death apparatus in eukaryotic cells [18] reported that the suicide machinery in bacterial cells is always present, it is only requires a trigger to activate it. Moreover, at least for E. coli, the straightforward choice is death caused by a stable intracellular toxin (in this case MazF). The choice of life over the "default" death requires a dynamic antagonistic process manifested either by the continued production of the unstable antitoxin (in this case MazE) or by a process that would prevent the degradation of the unstable antitoxin. Thus, cell death could be caused by anything that would prevent the continuous expression of the antitoxic protein MazE [4]. It should be noted that toxin/ antitoxin system is widespread in bacterial genomes and contribute to prokaryotic stress adaptation and the formation of persister cells biofilms [19]. The mechanism of toxin components is to exert their effects in different ways by targeting essential cellular functions such as DNA replication, protein synthesis, cell division, peptidoglycan biosynthesis (see above) and ribosome assembly.

However, RNA cleavage is the most prevalent mode of action in the pathway [20]. Vasperet al., [21]reported that in E.coli (see above), one of the most well characterized toxin-antoxin gene is $\mathrm{Ma}_{z} \mathrm{~F}_{9}$, an operan that encodes that intracellular MazF and its cognate antitoxin $\mathrm{MazF}_{9}$ toxin cleaves MRNA and DNA at 3,5 or 7 base recognition sequences in different bacteria and have been implicated in controlling cellular responses to various adverse conditions encountered by the bacteria in the host. Other mechanism of $\mathrm{MazF}_{9}$ in E. coli is $\mathrm{MazF}_{9}$ protein cleaves both MRNA and 16s ribosomal RNA and proposed to generate a subpopulation of 
stress ribosomes, thereby enabling the translation of leaderless transcript [22]. $\mathrm{MazF}_{9}$ system in E. coli are activated on exposure to numerous stress condition in an extracellular death factor-dependent manner. Another mechanism of action of compound $A_{1}$ $\mathrm{A}_{3}$ and $\mathrm{F}_{3}$ on the selected microbes E. coli and Bacillus subtilis was demonstrated by probing for the toxin-antitoxin $\mathrm{MazF}_{9}$ gene. This effect of toxin-antitoxin $\mathrm{MazF}_{9}$ biosensor leads to the death of the organisms between 0 to 180 minutes. The compounds have more lethal effects as they completely inhibited the E. coli at $180 \mathrm{~min}$ utes. In addition, the compounds have a better activity on $E$. coli than $B$. subtilis. The reasons for this activity must be as a result of differences in their cell wall compositions.

This results in Figure 1-8, showing that the mazEF system is responsible for approximately $90 \%$ killing by Spondiasmombin and other medicinal plant and antibiotics alike may illuminate, the until now elusive cause of $E$. coli killing by medicinal plant. Furthermore, medicinal plant like Spondiasmombin are considered to be bacteriostatic and bactericidal in action [23]. It should be noted that toxin system is widespread in bacterial genomes and contribute to prokaryotic stress adaptation and the formation of persister cells biofilms [19]. The mechanism of toxin components is to exert their effects in different ways by targeting essential cellular functions such as DNA replication, protein synthesis, cell division, peptidoglycan biosynthesis (see above) and ribosome assembly. The mechanism of action of toxin-antitoxin gene $\mathrm{MazF}_{9}$ include RNA cleavage [20]., MRNA and DNA cleavage and protein cleavage of both MRNA and 16s ribosomal RNA [22].

\section{Conclusion}

This is better method of measuring the mechanism of action of novel compound by triggering the toxin/antitoxin cell death of inherent nature of bacterial cell.

\section{References}

1. Oludaretemitope Osuntokun AO, Oluduro TO Idowu, AO Omotuyi, Assessment of Nephro toxicity, Anti-inflammatory and Antioxidant properties of Epigallocatechin, Epicatechin and Stigmasterol phytosterol (synergy) Derived from ethyl acetate stem bark extract of Spondiasmombin on Wister Rats Using Molecular method of analysis, Journal of Molecular Microbiology 1(1): 1-11.

2. Offiah VN, Anyanwu (1987) Abortifacient activity of an aqueous extract of Spondiasmombin leaves J Ethnopharmacol 26 (3): 317-320.

3. Idu M, Ataman JE, Akhigbe Ucho OG, Akinbo SF, Idu FK (2001) Studies on the nutritional value and anti-tumour property of the bark of Spondiasmombin. J Med Biomed Res.

4. Engelberg Kulka H, Glaser G (1999) Addiction modules and programmed cell death and antideath in bacterial cultures. Annu Rev Microbiol 53: 43-70.

5. Couturier M, Bahassi E M, Van Melderen L (1998) Bacterial death by DNA gyrase poisoning. Trends Microbiol 6(7): 269-275.
6. Yarmolinsky MB (1995) Programmed cell death in bacterial population. Science 2 67(5199): 836-837.

7. Jensen RB, Gerdes K (1995) Programmed cell death in bacteria: proteic plasmid stabilization systems. Mol Microbiol 17(3): 205-210.

8. Aizenman E, Engelberg Kulka H, Glaser G (1996) An Escherichia coli chromosomal "addiction module" regulated by ppGpp: a model for programmed cell death. Proc Natl Acad Sci 93(12): 6059-6063.

9. Gerdes K, Gultyaev AP, Franch T, Pederson K, Milkkelsen ND (1997) Antisense RNA-regulated programmed cell death. Annu Rev Genet 19: 49-61.

10. Metzger S, Dror IB, Aizenman E, Schreiber G, Toone M, et al (1988) The nucleotide sequence and characterization of the relAgene of Escherichia coli. J Biol Chem 263(30): 15699-15704.

11. Cashel M, Gentry DR, Hernandez VZ, Vinella D (1996) The stringent response. in Escherichia coli and Salmonella: cellular and molecular biology. $2^{\text {nd }}$ ed: Pp: $1458-1496$.

12. Abulreesh HH (2011) Multidrug Resistant Staphylococci in the Environment. International Conference on Biotechnology and Environment Management. IPCBEE18: 1-6.

13. Ramage HR, Connolly LE, Cox JS (2005) Comprehensive functional analysis of Mycobacterium tuberculosis toxin antitoxin systems: implications for patho genesis, stress responses, and evolution PLoS Genet 5: e1000767 (2009).

14. Zhu Z (2008) Sgs1 helicase and two nucleases Dna 2 and Exo1 resect DNA double-strand break ends. Cell 134(6): 981-994.

15.Schifano JM (2014) An RNA-seq method for defining endoribonuclease cleavage specificity identifies dual rRNA substrates for toxin MazF-mt3. Nat Commun 5: 35-38.

16. Masuda Y, Miyakawa K, Nishimura Y, Ohtsubo E (1993) chpA and chpB, coli chromosomal homologs of the pem locus responsible for stable maintenance of plasmid R100. J Bacterio 11 75(21): 6850-6856.

17. Weil M, Jacobson MD, Coles HS, Davies TJ, Gardner RL, et al. (1996) Constitutive expression of the machinery for programmed cell death. J Cell Biol 133: 1053-1059.

18. Raff M (1998) Cell suicide for beginners. Nature 306:119-122

19. Pandey CN, Rawal BR, Seema M, Harshad S (2005) Medicinal Plants of Gujarat $1^{\text {st }}$ Edn. India.

20. Jang KL, Livesley WJ, Angleitner A, Riemann R, Vernon PA (2008) Genetic and environmental influences on the covariance of facets defining the domains of the five-factor model of personality. Personality and Individual Differences 33: 83-101.

21. Vesper 0, (2011) Selective translation of leaderless mRNAs by specialized ribosomes generated by MazF in Escherichia coli. Cell 147(1): 147-157.

22. Sat B, Hazan R, Fisher T, Khaner H, Glaser G, et al. (2001) Programmed cell death in Escherichia coli: some antibiotics can trigger mazEF lethality. J Bacteriol 183(6): 2041-2045.

23. Schlessinger D, Eisenstein B (1998) Biological basis for antibacterial action. in Micro bial Disease, $3^{\text {rd }}$ ed. pp 52-61.

24. Tripathi H (2014) Genomic Identification of Potential Targets Unique to Candida albicans for the Discovery of Antifungal Agents. Curr Drug Targets 15(1): 136-149. 
This work is licensed under Creative Commons Attribution 4.0 License

DOI: 10.19080/IJCSMB.2019.05.555673

\section{Your next submission with Juniper Publishers will reach you the below assets}

- Quality Editorial service

- Swift Peer Review

- Reprints availability

- E-prints Service

- Manuscript Podcast for convenient understanding

- Global attainment for your research

- Manuscript accessibility in different formats ( Pdf, E-pub, Full Text, Audio)

- Unceasing customer service

Track the below URL for one-step submission https://juniperpublishers.com/online-submission.php 